\title{
Coronavirus Test of the European Union's Policy on the Rule of Law
}

\author{
Ákos Bence Gát \\ * Junior Research Fellow, University of Public Service, Eötvös József Research Centre, Europe \\ Strategy Research Institute, e-mail: gat.akos.bence@uni-nke.hu
}

\begin{abstract}
The issue of the rule of law has been on the European Union's (EU) agenda since the beginning of the 2010s. The legal history of the EU shows that the EU's approach to the topic of the rule of law underwent significant changes. Initially, the Member States called for guarantees of fundamental rights in EU institutions. This trend began to change in the late 1990s and early 2000s, when the possibility of European rule of law control over Member States and the predecessor of the current Article 7 of the Treaty on European Union (TEU) were introduced by the Treaty of Amsterdam. However, the idea that the EU institutions can constantly monitor the Member States in the name of the rule of law has only emerged and started dominating the European political agenda since the early 2010s. Over the last decade, the EU institutions have continuously expanded their toolkit for monitoring Member States in this regard.

Following calls from some Member States and the European Parliament, in 2014 the Commission set up the new EU framework to strengthen the rule of law. In the same year, the European Council introduced an annual rule of law dialogue. In 2016, the European Parliament proposed the establishment of an annual rule of law report that monitors all Member States. At first, the European Commission was reluctant to accept this idea, but finally it introduced an annual rule of law report in 2020. However, the EU's policy on the rule of law suffers from fundamental shortcomings, which were especially visible during the first wave of the coronavirus crisis in the spring of 2020. In the pandemic situation, it has become even more apparent that the EU's policy on the rule of law raises a significant issue of EU institutions exceeding their competences and stands on a questionable legal basis.

Criticisms formulated against Hungary during the pandemic have revealed that the EU institutions do not provide sufficient guarantees for an objective examination of the situation of the rule of law in the Member States. The situation brought about by the coronavirus has also raised a number of questions regarding the lawful functioning of EU institutions, which shows the need for a rule of law mechanism capable of verifying that the EU institutions themselves also properly respect the rule of law.
\end{abstract}

Keywords: European policy on the rule of law, conferral of competences, legality of the functioning of European institutions during the coronavirus pandemic 


\section{Introduction}

The rule of law is a constitutional concept which inherently has no fixed, universal definition. However, there is agreement that its key elements include lawfulness of political decisions, legal certainty, respect for fundamental rights, and the existence of checks and balances. In a state based on the rule of law, the legislative power itself has also legal, constitutional limits (Council of Europe, 2011, p. 10). In the last decade, a new European public policy has developed around the notion of the rule of law. Public policy is 'the action programme of one or more administrative or governmental authorities' (Hassenteufel, 2011, p. 7). This definition is also applicable to European policy on the rule of law as various EU institutions, EU politicians, non-governmental organisations and researchers have invested significant energy in developing newer and newer ways for the EU to monitor Member States in the name of the rule of law. Since 2011 numerous reports, resolutions, official documents and academic articles have shaped the action plan that the European Union continues to follow today. ${ }^{1}$ The aim of this paper is to provide a concise overview of European policy on the rule of law with a special emphasis on the impact of the coronavirus pandemic in this field.

The EU's approach towards the notion of the rule of law went through a significant change during the history of European integration. Initially, the fear was that citizens' fundamental rights would be threatened not by Member States, but by European institutions. It may seem odd in the context of current European politics, but originally it was national authorities which demanded stronger guarantees of fundamental rights for their citizens to defend against potential abuses by the European institutions, and not the reverse. Then a spectacular turnaround took place and EU institutions now take any opportunity to voice their concern about Member States not providing enough protection to the rule of law. The EU developed a complex, constantly expanding set of instruments among which parallels and duplications may be observed which reflect political and institutional concurrence between different $\mathrm{EU}$ institutions. In the spring of 2020, the first phase of the coronavirus pandemic provided an opportunity to observe how the EU's relatively new policy on the rule of law functions in exceptional circumstances. The coronavirus has created an extraordinary context, not only for the Member States but also for the EU's institutional system, in which the shortcomings of European policy on the rule of law become more apparent.

\section{The rule of law's changing role in the European Union from a legal historical perspective}

The European Communities, the predecessor of the EU, were primarily about economic rather than value-based cooperation (Téglási, 2014, p. 154). While the protection of fundamental rights became the premise of Member State constitutional practices after the World Wars, the protection of fundamental rights and the rule of law were only

1 For a more detailed analysis see Gát (2019). 
inserted into the treaties that shaped the predecessors of the EU after many decades of delay. In the first three decades of the European Communities, the founding Treaties did not mention fundamental rights, including only a few legal bases for the protection of a few special rights. Such special rights were, for example, a general prohibition of discrimination on the grounds of nationality, freedom of movement for workers, freedom to provide services, improved working conditions and improved standards of living for workers and equal pay for men and women (Ferraro \& Carmona, 2015, p. 3).

Initially, fundamental rights appeared only in symbolic declarations. Following the 1973 Copenhagen European Summit, the nine Member States of the European Communities adopted the Declaration on European Identity. ${ }^{2}$ This document states that sharing as they do the same attitudes to life, based on a determination to build a society which measures up to the needs of the individual, they are determined to defend the principles of representative democracy, of the rule of law, of social justice - which is the ultimate goal of economic progress - and of respect for human rights'. In 1977, the Parliament, the Council and the Commission adopted a brief declaration, comprising only two paragraphs, in which they emphasised that they 'stress the prime importance they attach to the protection of fundamental rights, as derived in particular from the constitutions of the Member States and the European Convention for the Protection of Human Rights and Fundamental Freedoms.'3

As the Community's legal, political and economic importance has increased, it has become increasingly essential for the new European political entity to provide legal guarantees for the protection of fundamental rights against potential breaches by European institutions. In this regard, the so-called Solange judgment of the German Constitutional Court of 29 May 1974 was a milestone. In its decision, the Karlsruhe Court stated that it would continue reviewing Community legislation from a fundamental rights perspective for as long as the European Communities failed to ensure the protection of fundamental rights to the same degree as Germany. In reaction to the judgment of the Constitutional Court, the Court of Justice of the European Union (formerly the Court of Justice of the European Communities, hereinafter: the Court) sought to establish guarantees for the protection of fundamental rights. In the light of today's debate on the rule of law in the EU, this may have been forgotten, and it should be emphasised that the Court, similarly to the 1977 statement by Parliament, the Council and the Commission, referred to the constitutional traditions of the Member States, and relied on them when it upheld that the protection of fundamental rights is part of the general principles of Community law. It later further extended the legal basis for the enforcement of fundamental rights and international conventions, in particular the European Convention on Human Rights, which became an additional source of inspiration.

Despite the developments in case law, the idea that there is an inherent fundamental rights gap of the European Communities is supported by the fact that, for a long

\footnotetext{
Déclaration sur l'identité européenne (Copenhague, 14 décembre 1973).

3 Joint Declaration of the European Parliament, the Council and the Commission on Fundamental Rights, 27 April 1977.
} 
time, the EU did not have its own instrument for the protection of fundamental rights. The so-called Charter of Fundamental Rights was proclaimed on 7 December 2000 in Nice. The proclamation of the Charter, however, was in the form of an interinstitutional agreement, which could not be considered equivalent to the Treaties. It would only be given the same legal weight as the Treaties much later, in the draft of the Treaty establishing a Constitution for Europe ('the Constitutional Treaty'). Since the draft Treaty was rejected in referenda in two Member States, however, the Charter remained a mere interinstitutional agreement. The Charter of Fundamental Rights was only elevated to the level of the Treaties around a decade ago, when the Treaty of Lisbon entered into force in 2009.

Regarding the Treaties, the first explicit reference to the rule of law only appeared 35 years after the establishment of the European Communities, in the 1992 Treaty of Maastricht. Again, it is important to note that back then, the issue of the protection of the rule of law had not been raised in relation to EU Member States, but basically in relation to third countries. At the same time, in line with the case law of the Court, Article $\mathrm{F}$ of the Maastricht Treaty stated that 'the Union shall respect fundamental rights, as guaranteed by the European Convention for the Protection of Human Rights and Fundamental Freedoms signed in Rome on 4 November 1950 and as they result from the constitutional traditions common to the Member States, as general principles of Community law' (Maastricht Treaty, Article F).

In comparison, the 1997 Treaty of Amsterdam brought about a significant change in approach. With the new Treaty, Article F (1) of the Treaty of Maastricht was amended as follows: 'The Union is founded on the principles of liberty, democracy, respect for human rights and fundamental freedoms, and the rule of law, principles which are common to the Member States' [Treaty of Amsterdam, Article 1(8)]. It can be observed that in this wording, the EU has progressed to referring to fundamental rights as its own principles, and there is no indication that these legal principles became part of the EU legal order thanks to the Member States' constitutional traditions.

The Treaty of Amsterdam also introduced the predecessor to current Article 7 of the Treaty on European Union, well known from the political debates of the past years. Article F.1 of the Treaty of Amsterdam stated that 'the Council, meeting in the composition of the Heads of State or Government and acting by unanimity on a proposal by one third of the Member States or by the Commission and after obtaining the assent of the European Parliament, may determine the existence of a serious and persistent breach by a Member State of principles mentioned in Article F(1), after inviting the government of the Member State in question to submit its observations. This procedure for sanctioning of Member States on their adherence to the rule of law has been strengthened and supplemented by the Treaties of Nice and Lisbon.

Based on the legal historical analysis of the Treaties, it can be established that, in the European Union, the protection of the rule of law is a relatively recent issue. It is also important to note that originally the Member States required the EU to introduce minimum guarantees of fundamental rights in its own legal system. Nowadays, this trend changed considerably and EU institutions require the Member States to provide more guarantees of the rule of law at national level. The idea of the EU monitoring the 
rule of law situation in Member States appeared in the Treaty of Amsterdam. This control still takes the form of an exceptional procedure, subject to strict conditions in Article 7 of the current Treaty on European Union.

In the procedure set out under Article 7(1), a four fifths majority of the Council and the consent of the European Parliament are required to determine a clear risk of a serious breach by a Member State of European values. In the procedure under Article $7(2)$, determining a serious and persistent breach of values shall be subject to the unanimous vote of the Heads of State or Government of the Member States and the consent of Parliament.

The Article 7 procedure, due to its exceptional nature, would not in itself have been capable of making rule of law control over Member States one of the top issues of European politics. The rule of law control over Member States is on the EU's political agenda because various European institutions and political actors translated it into a new European public policy. In the 2010s, one was able to observe a proliferation of debates, action plans, political and institutional documents examining the rule of law situation in certain Member States, especially the ones which joined the Union after 2004. Over the last decade, the EU's rule of law toolbox has been constantly expanding.

\section{Expanding institutional toolbox of European policy on the rule of law}

Over the last decade, various EU political actors and institutions have launched a number of initiatives with the aim of establishing a control over Member States in the name of the rule of law.

On 6 March 2013, the Foreign Ministers of four EU Member States, Germany, Finland, Denmark and the Netherlands addressed a letter to the President of the European Commission requesting the establishment of an EU rule of law mechanism. ${ }^{4}$ The letter sets out the main lines of action that EU institutions have followed to date in the field of policy on the rule of law, from the idea of a rule of law mechanism to the issue of potential financial sanctions, which were highly debated during the 2020 multiannual financial framework negotiations.

On 3 July 2013, the European Parliament adopted a resolution on the basis of the report of MEP Rui Tavares (European Parliament, 2013). The resolution contained a broad list of criticism formulated by the European left wing regarding the political and legal developments in Hungary after 2010. Similarly to the above mentioned letter of some foreign ministers, this resolution also already advocated the adoption of a swift and independent monitoring mechanism and an early-warning system coordinated at the highest political level to monitor EU values, without however clarifying the details of such a mechanism.

\footnotetext{
${ }^{4}$ Letter from the German, Dutch, Finnish and Danish Foreign Ministers to the President of the European Commission, 6 March 2013.
} 
On 11 March 2014, the European Commission announced in a communication the establishment of 'a new EU Framework to strengthen the Rule of Law' (European Commission, 2014) (hereinafter: rule of law framework), which was the first concrete tool for the EU to monitor the situation of the rule of law in Member States. This document outlined the mechanism that the Commission intended to apply in cases it would suspect that an EU Member State breaches the rule of law. The basis of this mechanism is a structured dialogue with the Member State concerned and consists of three phases. In the first phase, the Commission assesses whether there are any clear indications that the rule of law is at risk in a Member State. If, on the basis of its preliminary assessment, it concludes that there is a systemic threat to the rule of law, it will enter into a dialogue with the Member State and send the state concerned its 'rule of law opinion'. In the event that the first phase does not bring results, in the second phase the European Commission sends a 'rule of law recommendation' to the Member State, the main elements of which it makes available for the public opinion. In its recommendation, the Commission is supposed to clearly state the reasons for its concerns and call on the Member State to resolve the issues outlined within a set period of time. The third phase is the 'follow-up to the Commission's recommendation', in which the Commission monitors the implementation of the recommendation addressed to the Member State concerned. If that Member State does not follow the recommendation satisfactorily within the set deadline, the Commission may initiate one of the mechanisms provided for in Article 7 TEU.

The structure of the rule of law mechanism developed by the Commission is based on the analogy of the procedural structure applied in infringement procedures. The structured dialogue takes place in a similar way: the Member State concerned and the Commission communicate and negotiate with each other and further steps only take place if they fail to reach an agreement at any stage. However, significant differences may be observed between the two procedures in relation to the next steps. In the event of an infringement procedure, in the absence of an agreement between the Member State and the Commission, the Commission may refer the matter to the Court of Justice of the European Union. In comparison, in the rule of law framework the judicial phase is completely missing. For this reason, the sanctions that may be envisaged also differ significantly. In an infringement procedure, the Court can condemn the Member State and order it to change its national legislation or practice to fall in line with the Commission's expectations, and can impose a fine. The rule of law framework does not include similar legal sanctions, failing which the Commission can only exert pressure on the Member State by initiating one of the procedures under Article 7 TEU.

Shortly after the announcement of the Commission's rule of law framework, the Council developed its own rule of law instrument. In its press release of 16 December 2014, the Council announced that it would organise an annual political dialogue between Member States to promote and protect the rule of law. The Council emphasised that 'this dialogue will be based on the principles of objectivity, non-discrimination and equal treatment of all Member States'. It also stated that its mechanism 'will be without prejudice to the principle of conferred competences, as well as the respect of national identities of Member States inherent in their fundamental political and 
constitutional structures [...], and their essential State functions' (Council of the European Union, 2014a). The Council has thus set up its own rule of law instrument in parallel with the Commission's rule of law mechanism. On the one hand, this demonstrated that it did not want to remove completely the topic of the rule of law from the European political agenda. On the other hand, it also indicated that by limiting the procedure to an intergovernmental dialogue respecting the equality and sovereignty of the Member States, the Council wanted to keep the EU's rule of law control over Member States within strict boundaries. The reasons of this prudent approach were not only political, but also legal. At the next point, I will present more in detail that the Council's Legal Service found the idea of EU institutions controlling the rule of law situation in Member States highly problematic from a legal perspective.

The Council was not the only EU institution to criticise the Commission's rule of law framework. Although from a different standpoint, the European Parliament also voiced its dissatisfaction. The institution started to develop a third, alternative rule of law mechanism with the justification that it did not deem the Commission's solution to be sufficiently comprehensive. The Parliament's solution is set out in its resolution adopted on 25 October 2016, which proposed that the Commission should establish an EU mechanism on democracy, the rule of law and fundamental rights (European Parliament, 2016).

Unlike the Commission's rule of law framework, the rule of law mechanism proposed by Parliament would not only be applied to individual countries 'if necessary', on a case-by-case basis. At the contrary, all EU Member States would be regularly monitored each year and EU institutions would keep all Member States under continuous surveillance. This resolution outlined the structure of a mechanism in which the Parliament, as well as various non-governmental organisations, would have been assigned a much more significant role than in the Commission's rule of law framework.

Different EU institutions have proposed different ways for the EU to monitor the rule of law in the Member States, and these mechanisms even compete with each other. For example, the Commission rejected the Parliament's October 2016 proposal, stating that it had serious doubts about the need and the feasibility of an annual Report and a policy cycle on democracy, the rule of law and fundamental rights prepared by a committee of 'experts' and about the need for, feasibility and added value of an interinstitutional agreement on this matter. It explained that 'some elements of the proposed approach, for instance, the central role attributed to an independent expert panel in the proposed pact, also raise serious questions of legality, institutional legitimacy and accountability'. It considered that 'first, the best possible use should be made of existing instruments, while avoiding duplication' (European Commission, 2017).

The Commission nevertheless changed its position after a few years. In its communication of 17 July 2019, it announced the introduction of an annual rule of law report, through which it assesses the rule of law situation in each Member State on a regular basis (European Commission, 2019). However, a significant difference from the mechanism proposed by the European Parliament in 2016 is that, in its annual rule of law report, the Commission plays the central role. 
By this new rule of law instrument, the Commission sends a strong message of principle: it feels entitled to bring all Member States under constant political control. However, from a practical point of view, doubts may be raised as to whether this regular review affects all Member States to the same extent. Examples from recent years have shown that the Union has turned a blind eye to mass demonstrations and ongoing police violence against citizens in some Western European countries. At the same time, in case of other Member States that joined the EU more recently, the EU is willing to monitor closely every rule of law criticism that may appear against the government. The EU's policy on the rule of law raises a number of other similar dilemmas as well, which became especially visible during the coronavirus crisis and are worth closer examination.

\section{Rule of law policy during the coronavirus pandemic: growing concerns}

In spring 2020, the first wave of the coronavirus created a special context for the EU institutional system that systematically scrutinises the rule of law in Member States. While the predictable functioning of the state is an important element of the rule of law, during the pandemic, Member States took a series of emergency measures: in Italy, settlements and entire regions were hermetically sealed; in numerous Western European countries strict curfews were put in place, violations of which were punished by the police, and Member States closed the EU's internal borders one after the other.

Different countries defended themselves against the virus in different ways, but basically every Member State focused on the fight against the coronavirus. Hungary, which has been in the crossfire of EU rule of law criticism for about a decade now, also concentrated on its defence strategy. The government introduced a state of danger on the basis of Article 53(1) of the Fundamental Law, and on 30 March 2020 the Parliament adopted Act XII of 2020 on the containment of coronavirus. This law authorised the Government to introduce emergency measures to protect the country's citizens against the virus and to maintain the emergency measures taken earlier for this purpose. This law did not set a specific end date for the authorisation of the government; however, it expressly provided that the National Assembly could terminate the effect of the legislation when the state of danger is over. Even more, the law also provided the National Assembly with the power to revoke the authorisation given to the government at any time before the end of the period of state of danger, either in general or in the case of specific measures. The law also amended the Criminal Code and introduced a new form of fearmongering during the extraordinary period. Under Section 337(2) of the Criminal Code, a person who, during the period of a special legal order and in front of a large audience, states or disseminates any untrue fact or any misrepresented true fact that is capable of hindering or preventing the efficiency of the protection against the epidemic became punishable by imprisonment for one to five years.

The draft law was submitted to the Hungarian Parliament on 20 March 2020, and almost immediately became the subject of fierce international criticism. The critiques 
were based on two allegations: one that in Hungary the Government has been given unlimited authorisation to rule by decree, abolishing the scrutinising role of the Parliament, and the other that the authorities had drastically restricted freedom of expression. By 23 March, a Member of the European Parliament had sent an email to 704 Members of the European Parliament, expressing concerns about the situation of democracy and the rule of law in Hungary, and collected signatures for a joint letter she intended to send to the European Commission the following day (Mandiner, 2020). The social media was flooded with condemnatory declarations by various European politicians and non-governmental organisations. Representatives of international organisations also expressed their concerns, including the Council of Europe Commissioner for Human Rights, the Organization for Security and Co-operation in Europe Representative on Freedom of the Press, and the Secretary General of the Council of Europe. When the Hungarian law was adopted, 13 EU Member States 5 issued a joint statement highlighting the importance of the rule of law during the coronavirus crisis, including Member States in which much stricter measures were in place than in Hungary. ${ }^{6}$ On this occasion, the European Commission made more cautious statements than usual, indicating that it would carry out an examination on this issue of concern. During the crisis, the European Parliament switched to a restricted mode of operation via teleworking arrangements, in essence limiting its work to matters related to the coronavirus. In this context, on 17 April 2020, it adopted a resolution on EU coordinated action to combat the Covid-19 pandemic and its consequences. It used Paragraph 46 of this resolution to make sharp criticisms of Hungary and Poland, the only EU Member States singled out in this way (European Parliament, 2020). A number of lessons may be learned from these reactions in relation to the EU's policy on the rule of law, which has again revealed the fundamental dilemmas that characterise this European public policy.

\subsection{The issues of legal basis and the division of competences between the EU and the Member States}

The first and most fundamental question is on what basis the EU institutional system questions the protection measures of some Member State Governments in times of a global health crisis in the name of the rule of law. We may approach this dilemma in different ways.

In a moral sense, the question is how European organisations can justify criticising and exerting political pressure on the defence measures adopted by certain Member States during the most serious period of the Covid-19 emergency. When all European countries fight desperately for protecting human lives, such pressuring on some Member

\footnotetext{
Belgium, Denmark, Finland, France, Germany, Greece, Ireland, Italy, Luxembourg, the Netherlands, Portugal, Spain and Sweden (Bayer, 2020).

${ }^{6}$ For example, Pierre de Combles de Nayves drew attention in Dalloz, a major French legal journal to the severe sanctions for breaches of curfew measures in France (de Combles de Nayves, 2020).
} 
States makes necessarily their fight even harder. This moral, ethical question is maybe the most easily perceivable for citizens.

From a more political approach, the problem with such pressuring is that European institutions exert this pressure while they bear no political responsibility and are not accountable for handling the coronavirus crisis in Member States. It is obvious, that Member States' governments that are directly accountable to their citizens should have the liberty to choose the measures they found the best for containing the pandemic.

Finally, this issue can be approached also from a legal perspective, which means an inquiry in the legal basis of European rule of law control over Member States. It is worth examining this issue more in depth, since the question of legal basis constitutes a dilemma from the beginning of the construction of European policy on the rule of law. The inherent contradiction of the EU's policy on the rule of law policy is that EU institutions try to control Member States in the name of the rule of law, without having adequate legal basis to do so, in consequence by breaching themselves the very basis of the EU's rule of law. Article 2 TEU sets out the values of the EU and Article 7 sets out the procedure that may be used in the EU in the event that a potential breach of those values by a Member State occurs. Other instruments developed by the EU institutions in addition to this lack an adequate EU legal basis. In 2014, the Council's Legal Service also highlighted this problem in an expert opinion, ${ }^{7}$ which found that the Commission had neither the legal basis nor the competence to establish the rule of law framework introduced in 2014 (Council of the European Union, 2014b).

The Council's Legal Service pointed out that "according to Article 5 TEU, 'the limits of Union competences are governed by the principle of conferral'" The consequence of this is that 'competences not conferred upon the Union in the Treaties remain within the Member States' (Clause 15). The opinion points out that:

Article 2 TEU does not confer any material competence upon the Union but, similarly to the Charter provisions, it lists certain values that ought to be respected by the institutions of the Union and by its Member States when they act within the limits of the powers conferred on the Union in the treaties, and without affecting their limits. Therefore, a violation of the values of the Union, including the rule of law, may be invoked against a Member State only when it acts regarding a subject matter for which the Union has competence based on specific competence-setting Treaty provisions (Clause 16). [...] Respect of the rule of law by the Member States cannot be, under the Treaties, the subject matter of an action by the institutions of the Union irrespective of the existence of a specific material competence to frame this action, with the sole exception of the procedure described at Article 7 TEU (Clause 17).

This body, part of the General Secretariat of the Council, gives opinions to the Council in order to ensure that its acts are lawful and well-drafted both in form and content. The Legal Service also represents the Council in judicial proceedings before the European Court of Justice, the General Court and the Civil Service Tribunal. 
The Legal Service also stated that 'the non-binding nature of a recommendation does not allow the institutions to act by issuing such type of acts in matters or subjects on which the Treaties have not vested powers on them'. It added that 'to build a permanent mechanism for a rule of law study and proposal facility operated by the Commission on the combined bases of Article 7 TEU and Article 241 TFEU would undermine the specific character of the procedure of Article $7(1)$ - particularly concerning the way it can be initiated' (Clause 21). The Legal Service clearly concluded that:

There is no legal basis in the Treaties empowering the institutions to create a new supervision mechanism of the respect of the rule of law by the Member States, additional to what is laid down in Article 7 TEU, neither to amend, modify or supplement the procedure laid down in this Article. Were the Council to act along such lines, it would run the risk of being found to have abased its powers by deciding without a legal basis (Clause 24).

In recent years, the EU's policy on the rule of law has been able to evolve without major obstacles, despite the fundamental legal concerns expressed by the Council's Legal Service in 2014. The political narrative that has been repeatedly voiced in European political forums and the international media - that the rule of law is so seriously threatened in some EU Member States that the EU, as an organisation that places human rights and universal values above all, must respond - was able to override the legal problem that the EU has no competence to examine Member States' domestic policy in issues not affecting EU law. Despite this very basic legal dilemma, more and more statements and resolutions were issued to condemn the measures of the governments of certain Central and Eastern European Member States. However, several constitutional law practitioners and authors of political science drew attention to the importance of the division of competences within the European Union. French constitutional law professor Bertrand Mathieu, for example, deduced that democracy developed in nation states, so democracy is directly threatened if the right to adopt crucial political decisions is taken away from national governments and illegally transferred to supranational, international entities, in violation of Member State sovereignty. At the end of the day, this would necessarily lead to citizens lose their control on political decisions (Mathieu, 2017).

\subsection{The issue of objectivity}

During the coronavirus pandemic, while all the EU Member States introduced emergency measures, Hungary and Poland found themselves again in the main focus of investigations and criticisms. In its resolution of 17 April 2020, mentioned above, the European Parliament voiced its concerns about the rule of law in Hungary and Poland. Hungary was also the subject of a debate in the plenary session of the European Parliament on 14 May 2020, entitled 'Emergency governance in Hungary and its impact on the rule of law and fundamental rights. This uneven emphasis has once again drawn 
attention to the question if EU rule of law instruments are capable to ensure an objective rule of law control over Member States.

Objectivity is an essential element of any set of instruments, which in principle, is designed to protect the rule of law against political arbitrariness. However, the EU's policy on the rule of law is characterised by a lack of objectivity. This structural problem stems from the fact that although EU institutions conduct rule of law investigations in the name of legal principles, the procedures themselves are political in nature. On the one hand, the reason for this is to be found in the subject of the investigations, which is political in each and every case: EU institutions examine governmental policy measures and parliamentary decisions of Member States. On the other hand, it may also be observed that the debate on a measure can always be traced back to a division related to some deeper differences in political worldviews and visions of the European Union. Most of the debates on the rule of law can be traced back to broader debates on constitutional and political theory, surrounding the relationship between democracy and liberalism, or to the competition between federalist and nation state concepts of the European Union (Gát, 2019, p. 200-234). Third, the main actors in the rule of law policy are political institutions rather than neutral judicial forums, and consequently political considerations rather than objectivity play a key role in their decisions. With regard to the European Commission, former Commission President Jean-Claude Juncker said in a speech that the Commission is a political body and he wanted to make it highly political (Juncker, 2014). The European Parliament consists of elected representatives who take their decisions on a party-political basis. The Council consisting of the Ministers of the Member States is not a neutral institution either, but one of the main stages of European policy and diplomacy.

Against this background, the question of whether the EU's policy on the rule of law can itself become a tool of political arbitrariness is a logical one. In his book, professor of constitutional law, András Zs. Varga analysed the theoretical dangers of the totalitarian use of the rule of law concept in detail (Varga, 2019). He pointed out that there was a danger that the idea of the rule of law, originally intended to limit political arbitrariness, would become a means of achieving arbitrariness.

\subsection{The need for guarantees that EU institutions respect the rule of law}

In order for the EU's policy on the rule of law not to become an instrument of political arbitrariness, in addition to the settling of the above mentioned structural problems of legal basis and objectivity it is also extremely important to ensure that EU institutions themselves respect the rule of law, i.e. the lawfulness of individual policy measures, in their daily operation. With regard to the EU institutional system, dysfunctions were seen in this area even before the coronavirus crisis. In the European Parliament, for example, the debate on the Sargentini report that initiated the rule of law procedure against Hungary under Article 7 raised the question of how the extraordinary majority required to initiate the procedure is to be calculated. Hungary disputed the Parliament's procedure for not taking into account abstention votes cast when determining the 
voting results. In another case in 2019, during the appointment procedure of the members of the Von der Leyen Commission, in case of the Hungarian commissioner-designate, political and legal procedures were confusingly merged. In the autumn of 2019, the commissioner-designates from each country were heard in public by the relevant thematic committees of the European Parliament. The public hearing of the Hungarian Commissioner-designate was scheduled to take place in the Foreign Affairs Committee. However, referring to a potential conflict of interest, the MEPs of the European Parliament's Committee on Legal Affairs voted against the candidate in advance in a closed session, thus making it impossible for a public hearing to take place before the relevant parliamentary committee.

When the coronavirus epidemic broke out in the spring of 2020, several rule of law dilemmas arose over the functioning of the European Parliament. The Parliament's Rules of Procedure were not prepared for such an emergency and the EP switched to a virtually ad hoc mode of operation, without developing the appropriate legal environment. A Hungarian Member of the European Parliament exposed these anomalies in a scientific legal analysis (Szájer, 2020). He noted that 'there is no particular legal basis, which would exempt the institutions from the obligation to comply with the EU norms and standards in force.. [...] In the case of the European Parliament [sic] physical presence is an immanent, essential condition, core concept of the entire functioning, since all the provisions of the Rules of Procedure are based on the condition of Members' physical presence. Presence is a legal fact and it has numerous legal effects in the Rules of Procedure, in many cases related to the validity of acts.' The study details the legal uncertainties that have arisen in connection with the issues of quorum, parliamentary thresholds, the exercise of the right to speak and voting procedures.

Another characteristic contradiction in the functioning of the European Parliament during the coronavirus epidemic was manifested in the already mentioned debate in the European Parliament on 14 May 2020 entitled 'Emergency governance in Hungary and its impact on the rule of law and fundamental rights' (European Parliament, 2020a). The plenary debate was the result of the process described above, in which Hungary was accused of, among other things, restricting the freedom of expression. Paradoxically, however, the President of the European Parliament has repeatedly rejected the Hungarian Government's request for its Minister of Justice to speak on behalf of the Hungarian Government in the debate on Hungary (Magyar Nemzet, 2020).

\section{Conclusion}

The development of the legal history of the EU shows that initially Member States called for guarantees of the rule of law in EU institutions. This trend began to shift in the late 1990s and early 2000s, when a provision allowing for a European supervision of fundamental rights in the Member States in certain cases was inserted into the Treaty of Amsterdam. In practice, however, it was not until the beginning of the 2010s that the European political agenda became increasingly dominated by the discourse that the EU institutions were responsible for monitoring the rule of law situation in Member States. 
Over the last decade, the EU institutions have continuously extended their set of tools for monitoring Member States in the name of the rule of law. However, the EU's rule of law policy, as thus established, suffers from fundamental shortcomings, which were clearly revealed during the first wave of the coronavirus pandemic in the spring of 2019. The European policy on the rule of law is built on a questionable legal basis and lacks guarantees of objectivity. The EU rule of law monitoring is always directed at Member States; it does not hold the EU institutions to account, even though numerous recent dilemmas have arisen about their lawful functioning.

\section{References}

Bayer, L. (2020, April 1). 13 countries "deeply concerned" over rule of law. Politico. Online: www.politico. $\mathrm{eu} /$ article/viktor-orban-hungary-13-countries-deeply-concerned-over-rule-of-law/

Council of Europe (2011). Report on the rule of law adopted by the Venice Commission at its 86th Plenary Session. Online: www.venice.coe.int/webforms/documents/default.aspx?pdffile=CDL-AD(2011)003rev-f

Council of the European Union (2014a). Press release nr. 16936/14, 3362nd Council meeting, General Affairs. Brussels, 16 December 2014. Online: http://data.consilium.europa.eu/doc/document/ST-169362014-INIT/en

Council of the European Union (2014b). Opinion of the Legal Service, Communication from the Commission on a new EU Framework to strengthen the Rule of Law - compatibility with the Treaties. Online: http:// data.consilium.europa.eu/doc/document/ST-10296-2014-INIT/en

Déclaration sur l'identité europenne (Copenhague, 14 décembre 1973). Online: www.cvce.eu/obj/declaration sur_1_identite_europeenne_copenhague_14_decembre_1973-fr-02798dc9-9c69-4b7d-b2c9-f03a8db7da32. html

de Combles de Nayves, P. (2020, March 22). Ne rajoutons pas l'arbitraire à la catastrophe sanitaire. Dalloz. Online: www.dalloz-actualite.fr/node/ne-rajoutons-pas-l-arbitraire-catastrophe-sanitaire - .YBg8CS2ZNE4

European Commission (2014). Communication from the Commission to the European Parliament and the Council. A new EU Framework to strengthen the Rule of Law. Online: https://eur-lex.europa.eu/resource. html?uri=cellar:caa88841-aa1e-11e3-86f9-01aa75ed71a1.0023.02/DOC_1\&format=DOC

European Commission (2017). Follow up to the European Parliament resolution with recommendations to the Commission on the establishment of an EU Mechanism on Democracy, the Rule of Law and Fundamental Rights, adopted by the Commission on 17 January 2017. Online: www.europarl.europa. $\mathrm{eu} /$ oeil/spdoc.do $? \mathrm{i}=27630 \& \mathrm{j}=0 \& \mathrm{l}=\mathrm{en}$

European Commission (2019). Communication from the European Commission of 17 July 2019. Strengthening the rule of law within the Union. A blueprint for action. Online: https://ec.europa.eu/transparency/ regdoc/rep/1/2019/EN/COM-2019-343-F1-EN-MAIN-PART-1.PDF

European Parliament (1992). The Maastricht Treaty. Online: www.europarl.europa.eu/about-parliament/ hu/in-the-past/the-parliament-and-the-treaties/maastricht-treaty

European Parliament (1997). Treaty of Amsterdam. Online: www.europarl.europa.eu/about-parliament/hu/ in-the-past/the-parliament-and-the-treaties/treaty-of-amsterdam

European Parliament (2013). Resolution of 3 July 2013 on the situation of fundamental rights: standards and practices in Hungary (pursuant to the European Parliament resolution of 16 February 2012). Online: www.europarl.europa.eu/sides/getDoc.do?pubRef=-//EP//TEXT+TA+P7-TA-2013-0315+0+DOC $+\mathrm{XML}+\mathrm{V} 0 / / \mathrm{HU}$ 
European Parliament (2016). Resolution of 25 October 2016 with recommendations to the Commission on establishing an EU mechanism on democracy, the rule of law and fundamental rights. Online: www. europarl.europa.eu/sides/getDoc.do?pubRef=-//EP//TEXT+TA+P8-TA-2016-0409+0+DOC+XML+ $\mathrm{V} 0 / / \mathrm{HU}$

European Parliament (2020a). Agenda of the European Parliament plenary session of 14 May 2020. Online: www.europarl.europa.eu/doceo/document/OJQ-9-2020-05-14_HU.html

European Parliament (2020b). Resolution of 17 April 2020 on coordinated EU action to combat the COVID-19 pandemic and its consequences. Online: www.europarl.europa.eu/doceo/document/TA-92020-0054_HU.html

Ferraro, F. \& Carmona, J. (2015). Les droits fondamentaux dans l'Union européenne. Le rôle de la Charteaprès le traité de Lisbonne. Online: https://doi.org/10.2861/592904

Gát, Á. B. (2019). Küzdelem az Európai színtéren - a Magyarországgal szembeni „jogállamiság”-kritika feltáratlan összefüggései. Közép- és Kelet-európai Történelem és Társadalom Kutatásért Alapítvány.

Hassenteufel, P. (2011). Sociologie politique: l'action publique. Armand Colin. Online: https://doi.org/10.3917/ arco.hasse.2011.01

Juncker, J.-C. (2014, July 15). A new start for Europe. Opening statement in the European Parliament plenary session. Online: https://ec.europa.eu/commission/presscorner/detail/hu/SPEECH_14_567

Letter from the German, Dutch, Finnish and Danish Foreign Ministers to the President of the European Commission, 6 March 2013. Online: www.eerstekamer.nl/eu/documenteu/_brief_nederland_duitsland/ $\mathrm{f}=/$ vji8oh6slx9o.pdf

Magyar Nemzet (2020, May 12). Jött a válasz Brüsszelből: Varga Judit nem kap szót az Ep-ben. Hírtv. Online: https://hirtv.hu/hirtvkulfold/jott-a-valasz-brusszelbol-varga-judit-nem-kap-szot-az-ep-ben-2501170

Mandiner (2020, March 23). Cseh EP-képviselő tiltakozik a magyar veszélyhelyzetet meghosszabbító törvényjavaslat ellen. Online: https://mandiner.hu/cikk/20200323_cseh_ep_kepviselo_tiltakozik_a_ magyar_veszelyhelyzetet_meghosszabbito_torellen

Mathieu, B. (2017). Le droit contre la démocratie? LGDJ.

Szájer, J. (2020, April 6). Rule of law and the functioning of the European Parliament under the coronavirus pandemic - how to restore the lawful operation. Fidesz-eu. Online: https://fidesz-eu.hu/en/rule-of-lawand-the-functioning-of-the-european-parliament-under-the-coronavirus-pandemic-how-to-restore-thelawful-operation/

Téglási, A. (2014). Az emberi jogok védelmének nemzetközi rendszere. In Zs. Bende \& I. Halász (Eds.), Összehasonlító alkotmányjog. Fejezetek az alkotmány, az állam, az államszervezet és az alapvető jogok témaköréből. NKE Közigazgatás-tudományi Kar.

Varga, A. Zs. (2019). From Ideal to Idol? The Concept of the Rule of Law. Dialóg Campus. Online: https:// nkerepo.uni-nke.hu/xmlui/bitstream/handle/123456789/12507/web_PDF_From_Ideal_to_Idol.pdf; jsessionid=EDB476C4E8617752010B6B1EDD215CC2? sequence $=1$ 